\title{
THE FIRM IS A CREATIVE \\ INSTITUTION: THE DRIVING FORCE OF ENTREPRENEURSHIP
}

\author{
JAVIER ARANZADI DEL CERRO*
}

Fecha de recepción: 19 de junio de 2012.

Fecha de aceptación: 25 de junio de 2013.

Resumen: Este artículo presenta el papel de la empresa como institución social. En esta perspectiva, la responsabilidad social de la empresa consiste en fomentar, ampliar y desarrollar la empresarialidad de sus empleados. En lugar de hablar de la creatividad del genio individual deberíamos estudiar cómo estimular la creatividad de las personas dentro de las empresas. De esta manera el bienestar económico no se reduce a la posesión material, sino que el incremento de la riqueza económica se centra en el incremento de posibilidades de acción de las personas. Así, podremos avanzar un criterio de coordinación social. Dicha coordinación mejora si las posibilidades de acción personales ejecutadas en las empresas se amplían. El motor de este proceso social es la empresarialidad entendida como el desarrollo de la capacidad creativa de las personas en el contexto social y cultural en el que viven.

Palabras clave: Empresa, Institución Social, Creatividad, Empresarialidad, Ética, Coordinación Social.

Clasificación JEL: B53; L20; L26; M14.

Abstract: In this article, I approach the role of the firm as a social institution. I will do this by studying the firm from the personal interrelations that make it a social process. In this perspective, the social responsibility of the firm consists of enhancing the entrepreneurship of its employees. Instead of asking about individual creativity in isolation we should consider how to stimulate creativity in personal action, in entrepreneurial culture and in existing firms. In this view there is not only more welfare as we have more things but also

* Associated Professor of Economics, Universidad Autónoma, Madrid. Email: javier.aranzadi@uam.es. His last book is Liberalism against Liberalism, Routledge, London 2006.

Procesos de Mercado: Revista Europea de Economía Política Vol. X, n.으 2, Otoño 2013, pp. 17 a 38 
as we have more possibilities for action. And I can venture a criterion of social coordination: Coordination improves if the process of creating culturally transmitted personal possibilities for action in firms is extended. The driving force of this social process is entrepreneurship understood as the deployment of the person's creative capacity in the reality around her.

Key words: Firm, Social Institution Creativity, Entrepreneurship, Ethics, Social coordination.

JEL Classification: B53; L20; L26; M14.

\section{I \\ INTRODUCTION}

The aim of this brief paper is to expound a series of ideas about the firm which, in my view, should be obvious, but which it seems they are easily forgotten. I do not mean to reinvent the wheel, or to try to pass off as novelty what is already well known. I mean only to recall that the firm is a social institution, and therefore that its reason for being is social. In other words, the social dimension of the firm cannot be reduced solely to making money. This is an indispensable requirement, but insufficient. The recognition of the firm as a generator of wealth, of goods and services, shows us the outcome, the monetary achievements of entrepreneurial activity, but it does not show us the human process that generates that wealth.

We tend to use goods and services as a measure of social welfare. Thus the more wealth, expressed in goods and services produced, the more social welfare. This view is correct, but insufficient. Also insufficient is the casuistry, under the name of the Corporate Social Responsibility of firms, of specific measures by exemplary firms when resolving awkward or difficult situations. This growing interest in the study of the social and cultural context of entrepreneurial activity is to be welcomed. ${ }^{1}$ But this detailed study of particular conditions cannot make us lose sight of the general

\footnotetext{
1 See Shane and Venkataraman (2000).
} 
conditions that characterize the firm, regardless of specific sociocultural characteristics.

Among the different well-established theories of entrepreneurship Baumol (1968, 1993, 1996; Casson (1982); Kirzner (1973, 1979, 2000); Knight(1921); Leibenstein (1968); Nelson and Winter (1982); Schumpeter $(1934,1947)$ let's consider Kirzner's definition of entrepreneurship: «that element of alertness to possible newly worthwhile goals and to possible newly available resources». ${ }^{2}$ This entrepreneurship means that action is something active, creative and human. Reality in the widest sense is liable to be turned into resources. Anything, tangible or intangible, may be turned into a resource as soon as someone sees in it an opportunity for profit. In this respect Kirzner speaks of the world as a reality around us full of opportunities for profit. The opportunities are out there. The following quote corroborates this view of entrepreneurship:

Our world is a grossly inefficient world. What is inefficient about the world is surely that, at each instant, enormous scope exists for improvements that are in one way or another ready to hand and yet are simply not noticed. ${ }^{3}$

If we bear in mind these two aspects - the creative capacity of the entrepreneurial function and the worldly sphere in which it is deployed - the definition of pure entrepreneurship as the deployment of the person's creative capacity in the reality around her becomes clear. Any reality that makes sense to the actor is a field of action for entrepreneurship. Therefore the importance of social institutions and culture as constituent elements of personal action is not based on external considerations but on the fact that both elements, along with personal action, constitute "what is human», where the actor develops the entrepreneurial function. So, entrepreneurship is concerned with the discovery and exploitation of profitable opportunities. ${ }^{4}$ My aim is to investigate the role of the firm as a social institution. We will do this by

\footnotetext{
2 Kirzner (1973) p. 35.

3 Kirzner (1979) p. 135.

4 Shane and Venkataram (2000) p. 217.
} 
studying the firm from the personal interrelations that make it a social process. In this perspective, the ethical justification and social responsibility of the firm consists of enhancing the real possibilities of persons. As A. Etzioni says and G. Brenkert echoes: «by promoting new patterns, [entrepreneurs] help bring society and its components units in touch with a [new moral] reality». ${ }^{5}$ In this view there is not only more welfare as we have more things but also as we have more possibilities for action. Instead of focusing on goods and services, this view considers freedom of action, and there will therefore be more social welfare as our possibilities for action increase. That is, the firm contributes to social welfare by increasing the instrumental plexus of tools, things, services, knowledge, behavior patterns, etc. that weave our social warp. In a word, this paper seeks to recall that the firm is a social institution, and as such its essence concerns individuals, their needs and the possibilities of fulfilling them. As Solomon points out: «it views business as a human institution in service to humans and not as a marvelous machine or in terms of the mysterious "magic" of the market.» 6

The structure of this paper is as follows. In section (2) I will pay attention to what a social institution is. In section (3) I will link together the concepts of creativity and entrepreneurship for in section (4) set out the central idea of this paper that the social role of the firm is to foster the entrepreneurship, i.e. the creativity of his employees. Hence, in section (5) I can launch the concept of entrepreneurship as the social capital of the firm. And I will close up in section (5) with concluding remarks.

\section{II}

\section{THE OBJECT OF SOCIAL INSTITUTIONS}

The term institution designates the modes of behavior established by society and introduced into social life. Each culture transmits duties, and does so through socializing institutions. We could say

\footnotetext{
5 Brenkert (2009) p. 460.

6 Solomon (2004) p. 1024.
} 
that the structure of these duties is not a mental model for use, but a model for doing. As Aristotle says: «the end aimed at is not knowledge but action. ${ }^{7}$

I can define the institutions as the regular forms of life in common of individuals. So any institution realizes three functions: (1) Satisfy needs. (2) Coordinate the behavior of individuals. (2) Provide norms of conduct and values shared by individuals. As D. North (1991) says:

Institutions are the humanly devised constraints that structure political, economic and social interaction. They consist of both informal constraints (sanctions, taboos, customs, traditions, and codes of conduct) and formal rules (constitutions, laws, property rights) ${ }^{8}$

In principle, persons come into contact with firms as institutions for the satisfaction of needs. Such firms are stabilized in entrepreneurial cultures, i.e. in behavior patterns that allow them to produce goods and services. Here we find the homogenizing aspect of firms and the use of individuals as means of production. But productive activity is carried out by persons who procure their personal development and transform entrepreneurial relationships so as to fulfill their aspirations. Thus emerges the vital tension in which any human action unfolds. A tension between the stabilization of behavior and change. ${ }^{9}$ That is, persons are productive in a society with an already institutionalized division of labor. In essence, persons attain fulfillment as such only by living with other persons in social institutions that configure the ordinary world with meaning that we call culture.

In this approach, institutions constitute an integrated system where the expectations of the roles are rule-governed. This rule must be interpreted as a reciprocal stabilization of conduct. With this conception of expectations, one can explain the origin of the division of labor, which is the basis of economic progress. The

\footnotetext{
7 Aristotle (1969) pp. 1095-6.

8 North (1991) p. 97.

9 Brenkert (2009).
} 
division of labor is an expectation of the role. It is a particular case of great importance in the process of institutionalization. The division of labor is a role insofar as it enables people to specialize in a task, and to expect the exchange of the goods produced by each person. This possibility of exchange is what the market economy is based on. This typification of the expectation in the exchange is based on the fact that the division of labor has become rule-governed, it has become institutionalized. Every person has his or her roles defined by the company. As Solomon (1992, p. 163) says «buyer» and «seller» are established roles within an organized system.

This rule-governed dimension of social institutions is of maximum importance. The unity of meaning of the institutions enables them to be dynamic. The institution has not only made it possible to achieve the ends desired in the past, but it has to make it possible, in each present action, to achieve the ends that each person determines. As North points out: «They [institutions] evolve incrementally, connecting the past with the present and the future; history in consequence is largely a story of institutional evolution in which the historical performance of economics can only be understood as a part of a sequential story». ${ }^{10}$ This process of competition has no negative connotations because the social interrelations and the market exchanges tend to coordinate the expectations, provided that the person complies with the moral norms. Using the expression used in game theory, I can say that the interrelations and the market exchanges are positive sum. The expansion of the possibilities of action, of disposing of greater means is the consequence of the fact that competition is a positive sum game. The world «culture» in its general sense indicates everything whereby the person develops and perfects her many bodily and spiritual qualities. Solomon (1992, pp. 125-135) defines corporate culture as shared knowledge, established experience and values. It is an established group of people working together. But these shares values imply thinking in ourselves in relation to others. In this view, the typical opposition between moral

\footnotetext{
10 Op.cit., p. 97.
} 
thinking and self-interest disappears because pursuing my personal goods promotes those of others. So, the moral thinking is not external to self-interest, but something internal to the login of personal action. The observed reality is individual action. But action with other individuals is social action, and action with meaning is cultural action. As a consequence of this formal structure we can highlight the incorrectness of studies that seek to set the individual against society. As Solomon points out: «What is best in us - our virtues- are in turn defined by the larger community, and there is therefore no ultimate split or antagonism between individual self-interest and the greater public good». ${ }^{11}$ An opposition between the isolated individual and society conceals the intrinsic relationship between the various dimensions of action. Such action is substantively individual but with inseparable social and cultural dimensions. As Freeman says: «it does not make much any sense to talk about business or ethics without talking about human beings». ${ }^{12}$

III

\section{THE CREATIVE PROCESS AND ENTREPRENEURSHIP}

Creativity is not, therefore, a mere whirlwind, but the transcending of a given and established framework. Any innovation needs the established market on which to draw attention to its individuality. That is, every change drives market relationships, making it impossible to attain the state of repose that characterizes economic stability in the neoclassical model of mainstream economics. To understand creativity we must not confine ourselves to the product already produced, to the finished work, but rather investigate the creative process that gives rise to it. Schumpeter (1947), the celebrated Austrian economist, spoke of creative destruction, implying with this concept that every economic innovation was an abandonment of economic equilibrium. Each change impels relations in the market, making it impossible to reach

\footnotetext{
11 Solomon (2004) p. 1023.

12 Agle et al. (2008) p. 163.
} 
the state of rest which characterizes economic stability. This expression has been much repeated, but it does not capture the essence of the problem. Rather than destruction, one should speak of the retention and expansion of possibilities. Destruction would occur when a previously satisfied need could not be met with a new product. Creative innovation is not a reduction but rather an enlargement of the satisfaction of needs and an enlargement of the possibilities of action Kirzner (2000). So, the new combinations create a new source of potential value. Michael Porter (1996) acknowledged the need of the concept of value creation for effective firm strategy. And now is commonly recognized that for the dynamism of an economic system both value creation and value realization are needed Teece et.al. (1997). As Ghoshal, Bartlett and Moran (1999) say what we need is: «a new corporate philosophy that explicitly sees companies as value-creating institutions of society». ${ }^{13}$ Let us take an interactive view of creativity based on three elements: the person, culture and social institutions. In other words, entrepreneurial innovation has not only a personal dimension, i.e. the creator, but also a socio-cultural dimension.

Let us analyze the assertion of Herbert A. Simon (1969), Nobel laureate for Economics, to confirm the importance of this interactive approach. Simon proposed to the American Psychological Association that his computer program, called BACON, be considered creative, as it could replicate the solving of some of the most creatively demanding problems in science, such as Kepler's laws. Thus Simon, focusing solely on the creative product or idea, asserted that if $\mathrm{A}$ is considered a creative product or idea, and $\mathrm{B}$ is another idea or product indistinguishable from $\mathrm{A}$, then, we must accept that $B$ is also creative. The assertion clearly has a crushing logic: if $A$ and $B$ are equal, by logical identity they must have the same properties. What is wrong in this reasoning applied to creativity, innovation and the market process?

M. Csikszentmihalyi (1996), a psychologist specialized in the subject of creativity, pointed out that this criterion cannot be

13 Ghoshal, Bartlett and Moran (1999) p. 19. 
applied to the real world. That is, creativity is intelligible only in its social and historical context. Consider a painting by Rembrandt - a highly creative painter- and compare it with a copy that any forger might make, so accurate that the two cannot be told apart. Should we claim, with Simon, that this second painting is creative? Clearly not. The essential difference is that Rembrandt, in his time, introduced various new techniques into the cultural field of painting. These variant techniques were recognized as such by the masters, critics and patrons of the time who taught, transmitted knowledge and passed judgment on what was painted. That is, the institutional environment regarded the variants introduced by the painter as novel and useful, enabling symbolic representation in painting to progress.

Once recognized as such, they were integrated with existing artistic techniques by masters and critics. Once change occurs within culture, it is assimilated by the dominant institutions and homogenized. That is, it becomes part of the tradition and is transmitted to new practitioners. Thus, once such techniques are assimilated, their creative nature disappears and they become normal techniques within the tradition. We may conclude that Rembrandt for his part was creative, for he created something new and useful i.e. that was successfully applied. The second painter, by contrast, showed only a command of the given techniques. He generated no novelty in the current state of painting, or new artistic possibilities. We may conclude, therefore, that it is impossible to tell whether an object or idea is creative by merely contemplating it.

We should therefore distinguish between entrepreneurship, as defined earlier, i.e. the ability of individuals to create new ends and means of action in the reality around them, and the figure of the successful executive, which dominates today's entrepreneurial methods. This is what makes it so difficult to create entrepreneurs. Creativity may be explained and studied and, little by little, psychologists are supplying techniques for improving it. But at the moment, creativity is a faculty that is learned, and teaching it is quite difficult.

I may say that society is a process of creating possibilities for action that are realized in social institutions and transmitted 
culturally. In this dynamic view, society is a spontaneous process, i.e. it is based on the will of persons and is not the product of an arbitrary imposition by a centralizing and regulating body Mises (1996); Hayek (1976, 1989); Huerta de Soto (2010). It is a process of human relationships structured in social institutions such as the family, law, language, the market, etc. And it is a process that transmits forms of access to reality from generation to generation. We may reformulate this premise and postulate the following: the more individual possibilities for action it generates, the more efficient an institutional and cultural framework will be. That is, we may venture a criterion of social coordination allowing us to define entrepreneurial efficiency as a social institution according to the possibilities for action that firms generate. I would like to suggest a criterion of qualitative efficiency based on the real possibilities of individuals. The Nobel Prize winner for Economics Amartya Sen $(1999,2002,2009)$ spoke along the same lines: ${ }^{14}$

Individual freedom is quintessentially a social product, and there is a two-way relation between (1) social arrangements to expand individual freedoms and (2) the use of individual freedoms not only to improve the respective lives but also to make the social arrangements more appropriate and effective. ${ }^{15}$

A. Sen's work is highly significant because it indicates the growing interest of orthodox academic economics in seeking theories to explain social reality without reducing it to a set of variables that may be manipulated mathematically as a matter of maximizing utility. The sole message of this paper is that the study of economics must be based on the persons that produce and generate the process. As Solomon says: «by ignoring such "intangible" features of business life as company moral and

${ }^{14}$ It is impossible here to deal with the capabilities approach developed by A. Sen and M. Nussbaum Nussbaum and Sen (1993). The first point should make the differences - remarkably I would say- between Sen and Nussbaum approaches. For instance, Sen (2009) presents what he considers to be distinctive of his approach, and Nussbaum (2011) does the same. For a general and critical assessment of both approaches see H. Richardson $(2000,2007)$.

15 Sen (1999) p. 49. 
coordination in favor of the measurable quantities listed in the financial pages, we are destroying the corporation as community and, consequently, as a fully functional human institution». ${ }^{16}$ An attempt to account for the market by looking merely at what is produced will show us only statistical information on amounts of goods and services and prices. It will be vital information in ascertaining the state of the market, but it will not explain the process. In order to understand the generation of wealth we must focus on the motivations, wills, preferences and rules of individuals.

IV

\section{THE SOCIAL ROLE OF THE FIRM}

Let us use the interactive view of creativity to approach the firm. The first thing we note is that entrepreneurial innovation has not only a personal dimension, i.e. the creator, but also a socio-cultural dimension.

We now have an interactive view of creativity and entrepreneurship linking the person, the firm and entrepreneurial culture. ${ }^{17}$ We should be clear that these are not three distinct realities but three moments in the same process. These three moments are closely interlinked, so any changes in any one of them affect the creative process. Rather than speaking of what creativity is, we should ask where creativity comes from. In this view the social importance of the firm is huge: the firm's social responsibility is to enhance the possibilities of persons. The assertion that any person has the ability to create to a greater or lesser extent is not an exaggeration but quite the reverse. It highlights a current problem of great importance when firms need to innovate at high speed. It highlights the fact that in firms there is much wasted talent. Jack Welch, until recently president of General Electric, said:

\footnotetext{
16 Solomon (1992) p. 151.

17 On this point Aranzadi (2006, 2011).
} 
The talents of our people are greatly underestimated and their skills underutilized. Our biggest task is to fundamentally redefine our relationship with our employees. The objective is to build a place where people have the freedom to be creative, where they feel a real sense of accomplishment - a place that brings out the best in everyone. ${ }^{18}$

In this respect S. Ghoshal and C.A. Bartlett, echoing J. Welch, define the new social dimension of the firm:

Rather than accept the assumption of economists who regard the firm as just an economic entity and believe that its goal is to appropriate all possible value from its constituent parts, we take a wider view. Our thinking is based on the conviction that the firm, as one of the most significant institutions in modern society, should serve as a driving force of progress by creating new value for all of its constituent parts. ${ }^{19}$

This is a view that implies an extension of economics. Firms occupy a central position as basic institutions in society. It is a dynamic view that shows the firm's importance as a behavior pattern in social relations in which the lead role is played by the person and the driving force is entrepreneurship.

To press deeper the criterion of entrepreneurial efficiency I define economic efficiency as the enhancement of persons' possibilities for action. ${ }^{20}$ The first aspect of this criterion is that it is dynamic. Its coordination lies in the process of social interaction that progressively eliminates inefficient situations. Thus an economic, social and cultural system will be more efficient if it increases personal possibilities for action. That is, a situation will be more efficient where a person's prospects of action increase. And conversely, a social and cultural situation will be more inefficient if the possibilities for action that it affords to persons are more limited.

18 S. Ghoshal and C. Bartlett (1997) p. 21.

19 Op. cit., p. 27

20 P. Koslowski (1996, p. 53) status emphatically that the market allow not only freedom of consumption but also of action and production. 
However, we should supplement this criterion, for if we assert only the first part and stop at an increase in personal possibilities, it could be inferred that the more freedom of individual action we have, the better coordinated society is. Thus we could reach the paradoxical situation of asserting that the more murderers, drunks, thieves, etc. there are, the better coordinated society is. Something that no one accepts. That is, this first formulation of the criterion provides an element that is necessary but insufficient in itself. This first aspect concerns personal freedom of choice. But in the course of this paper I have argued that all individual action has a social dimension and that, as a result, the institutional order is maintained by personal actions. Therefore it is necessary to supplement the criterion of coordination from the social perspective and assert that the more entrepreneurial and social coordination it generates, the more efficient personal action will be. Thus we can assert that all behaviors that we normally regard as antisocial or pernicious, such as theft, murder, fraud or drug addiction, are inefficient because with them it is impossible for society to function, and much less so an economy based on theft. ${ }^{21}$

As we have developed the relationship between personal action, institutions and culture, the criterion may be formulated in three ways. Each one refers to each element's contribution to the system presented in figure (1). That is, as Csikszentmihalyi says (1996), when speaking of creativity we must take a systematic view. Instead of asking about individual creativity in isolation we should consider how to stimulate creativity in personal action, in entrepreneurial culture and in existing firms. We may formulate the coordination criterion with reference to each element. (1)

21 This efficiency criterion requires the two formulations in order to correspond to the two views of human freedom. Our first formulation refers to the conception of freedom as «freedom from». In this view, the person is free from institutions to do what she or he likes. It represents the freedom of indifference. One may do this or that. In this view a person who chooses to be a thief is as free as one who chooses to undertake a great enterprise. This first view presents the freedom of indifference. To distinguish between such behaviours I have introduced the second view corresponding to the concept of freedom as «freedom for». This view presents the person as a generator of positive actions. It presents man's freedom in the search for excellence in action. See S. Pinckaers (1985). 
Regarding firms the criterion is: the more personal possibilities for action they afford, the more efficient firms will be. (2) Regarding entrepreneurial culture: the more possibilities for action they foster, the more efficient cultural transmission mechanisms will be. (3) Regarding individual action: the greater its contribution to the firm and to entrepreneurial culture, the more efficient action will be. If we bear in mind that this separation is analytical and that the sole existing reality is man in action, we may sum up the three criteria in just one: coordination improves if the process of creating culturally transmitted personal possibilities for action in firms is extended.

This systematic criterion allows us to counter a common criticism. It is often objected that the outcomes of an institution and culture are acceptable only from within the relevant institutional and cultural prerequisites. Thus, for example, the working of the market is accepted provided that we accept the validity of private property as an institutional prerequisite. If for moral reasons we reject private property, the outcome of the market is unacceptable and we must regard its supposed efficiency as fallacious, and above all unfair and greedy Moore (2002, 2005a, $2005 b)$. Is this objection valid? With the dynamic and systematic criterion propounded above, it may be rejected, as institutional prerequisites are an essential part of personal action. Institutions and culture are not givens external to action, and therefore they are liable to appraisal. With the efficiency criterion institutions and cultures may be appraised according to the personal possibilities for action that they afford. The only fact that is irreducible, i.e. axiomatic, is action as the primary human reality Mises (1996). This primary reality is human action, which consists of the deliberate seeking of certain valuable ends with scarce means.

$\mathrm{V}$

\section{ENTREPRENEURSHIP AS SOCIAL CAPITAL}

It is fashionable to speak of social capital. To quote two widely prestigious theorists, the economist G. Becker and the sociologist J.S. Coleman recognize that individual behavior is directly 
influenced by the actions of other people. ${ }^{22}$ But in my view, the definition that they give of social capital, and by extension of social reality, is disappointing. They define social capital as «a variable along with goods and services in a stable extended utility function». ${ }^{23}$ In line with the definition of economics offered by Lionel Robbins (1969), these authors regard social capital as a variable that is given, and that is therefore known and quantifiable. This is a static view that does not account for the dynamic reality that is the person and her constituent dimensions. As Ghoshal, Bartlett and Moran (1999) say: «corporations, not abstract economic forces or governments, create and distribute most of an economy's wealth, innovate, trade and raise living standards». ${ }^{24}$ These two different concepts of the firm give two different concept of competition «static» or «dynamic». Moran \& Ghoshal say on this point:

At the heart of these different perspectives on the role of the firm lies ... a different view about the concept of efficiency itself. In much conventional economics, efficiency is a static concept, as is appropriate in acontextual, equilibrium analysis. However, in a more contextual and dynamic view, the notion of efficiency is much more problematic. ${ }^{25}$

And these different approaches of efficiency have, as consequence, a very different vision on the economic process. From a «static» point of view the resources are "given» so in any economy interchange what one person wins is the other person's lose. As Ghoshal, Bartlett and Moran say: "Static efficiency is about exploiting available economic options as efficiently as possible... In this zero-sum world, profits must indeed come at the expense of the broader society». ${ }^{26}$

The social institutions, in this case, firms, have their own dynamism, which depends on the opportunities that enable their

\footnotetext{
22 See G. Becker and K.P. Murphy (2000).

23 Op. cit., p. 8.

24 Ghoshal, Bartlett and Moran (1999) p. 9.

25 Moran \& Ghoshal (1999) p. 407.

26 Ghoshal, Bartlett and Moran (1999) p. 12.
} 
members to exercise their creativity and capabilities. So following Moran and Ghoshal (1999) I can define the economic process as a value-creating process based in the following steps: (1) Universe of all possible resource combinations. (2) Perceived possibilities. (3) Productive possibilities. (4) Productive opportunities. And they affirm: «as many firms of different forms and sizes engage in this process, each broadens the scope of exchange in ways that allow it to focus on some fragmented bits of the knowledge that Hayek (1945) talked about». ${ }^{27}$ Creativity action is the result of our ability to project ourselves and to envisage what may exist in the future Shane (2000); Venkataraman, (1997). The background of action should not be sought in the past but in the attempt to get a more profitable present out of a future that does not exist. ${ }^{28}$ Any person, however unadventurous, undertakes a project outside her immediate area of development. The person has the ability to procure information that motivates her to act. If we reduce the entrepreneurial function to mere knowledge there is no room for creative capacity, a capacity that consists of seeing more possibilities where there is apparently nothing. It is not, as is often said, that person with great creative capacity need little information in order to create great firms, but rather the other way round: such persons are able to create more practical information than others, which means we cannot confine the entrepreneurial function to great geniuses. Any person, by the fact of being a person, has this ability which is not reducible to objective knowledge. ${ }^{29}$

As we have said the social function of the firm consists of fostering its employees' creative capacity. Not as a form of social benefit or the like. In fact the firm's essential function is to enhance the real possibilities of its employees. The greater these possibilities, the greater the possibilities of monetary profit. There

27 Moran and Ghoshal (1999) p. 405.

28 The same idea was masterfully expressed by Professor Julián Marías in the following words: «My life is not a thing, but rather a doing, a reality projected into the future, that is argumentative and dramatic, and that is not exactly being but happening» (Marías , 1996, p. 126). More bluntly, Peter Drucker says: «the best way to predict the future is to create it» (P. Drucker, 1998, p. 197).

29 See Dew, Velamuri and Venkataraman (2004). 
is a wider range of possibilities to try out. Therefore we must not reduce the firm's function to that of making money and paying taxes. This is necessary, but not enough. Milton Friedman, Nobel laureate for Economics, says:

The social responsibility of business is to increase its profits. Few trends could so thoroughly undermine the very foundations of our free society as the acceptance by corporate officials of a social responsibility other than to make as much money for their stockholders as possible. ${ }^{30}$

We may share Friedman's idea, but the following questions arise. How do we increase profits? What is the essence of the productive process? What needs to be encouraged and increased? The answer can be no other than the entrepreneurship of persons. This is the way to increase profits: creating, creating and creating! But this involves taking account of the efficiency criterion that we described in our previous section: entrepreneurial coordination and wealth increase if the process of creating culturally transmitted personal possibilities for action in firms is extended. All the fundamental Friedman's work on micro theory of consumption, monetary policy and his defense of free market economy can be integrated in a more general and systematic framework. As E. Freeman says: «Better stakeholder theory focuses us on the multiplicity of ways that companies and entrepreneurs are out there creating value, making our lives better, and changing the world». 31

\section{VI}

\section{CONCLUDING REMARKS}

The current crisis, with its constant corporate and financial scandals, is having a very dangerous effect. It is calling into question the role of the market economy and the importance of the firm

\footnotetext{
30 Friedman (1970)

31 Agle et al., (2008) p. 166.
} 
as a social institution. As Ghoshal says: «Of far greater concern is the general delegitimization of companies as institutions and of management as a profession».32 Nowadays there is a general perception that the Schumpeterian destructive aspect of the market process dominates the economic reality. Hence market economy is accused of being essentially greedy and pernicious. It is perceived the «inmorality» or «amorality» of capitalism (Freeman, 2000, p. 171). Obviously there are lots of examples of such greedy and in-moral behaviors in our economics. But to illustrate the contemporary corporate culture in such destructive terms is a very narrow vision. ${ }^{33}$ Let's introduce Freeman's Principle of Continuous Creation: «business as an institution is a source of the creation of value» ${ }^{34}$ to compare it the previously mentioned Schumpeterian creative destruction idea. Schumpeter spoke of creative destruction. In his view each change impels the relations in the market, making it impossible to reach the state of neoclassical equilibrium. But in my opinion creative innovation cannot be a reduction, but rather the development of human capabilities and the enlargement of the possibilities of personal action. As Freeman nicely says: «the beauty of modern corporate form is that it can be made to be continuous, rather than destructive. One creation doesn't have to destroy another; rather there is a continuous cycle of value creation that raises the well-being of everyone». 35

The only reality we observe is personal action within her cultural and institutional. And personal action always has possibilities in plural. With the coordination criteria presented I can say that the social coordination improves if the process of creation of individual possibilities of action which is carried out in the social institutions, in our case, the firm, is extended. There is a retention of possibilities that is formed in the institutions and is transmitted culturally. In that moment emerges entrepreneurship, the creative tension that expands, maintains or diminishes the

\footnotetext{
32 Ghoshal (2005) p. 76.

33 Dobson (2009).

34 Freeman (2000) p. 177.

35 Freeman (2000) p. 177.
} 
possibilities of action. In this process enter into action all the elements that characterize human action as a dynamic, historical process, open to the future and, of course, subject to error and failure.

\section{BIBLIOGRAPHICAL REFERENCES}

Agle, B., Donaldson, T., Freeman, E., Jensen, M., Mitchell, R. \& WoOD, D. (2008): «Dialogue: Towards Superior Stakeholder Theory», Business Ethics Quarterly, 18 (2): 153-190.

ArANZADI, J. (2006): Liberalism against Liberalism, Routledge, London.

- (2011): «The Possibilities of the Acting Person within an Institutional Framework: Goods, Norms and Virtues», Journal of Business Ethics, 99(1): 87-100.

Aristotle (1969): Nicomachean Ethics, translated by D. Ross, Oxford University Press, Oxford.

Baumol, W. (1968): «Entrepreurship in Economic Theory», American Economic Review, Papers and Proceedings, 58: 64-71.

- (1993): «Formal Entrepreneurship theory in Economics. Existence and Bounds», Journal of Business Venturing, 8: 197-210.

- (1996): Entrepreneurship, Management, and the Structure of Payoffs, MIT Press, Cambridge, MA.

Becker, G. and Murphy, K.M. (2000): Social Economics, Harvard University Press, Massachussets.

BRENKERT, G. (2009): «Innovation, Rule Breaking and the Ethics of Entrepreneurship», Journal of Business Venturing, 29: 448464.

CAsson, M. (1982): The Entrepreneur, Barnes \& Noble Books, Totowa, NJ.

Csikszentminalyi, M. (1996): Creativity. Flow and the Psychology of Discovery and Invention, HarperCollins Publishers, New York.

Dew, N., Velamuri, S.R. \& Venkataranam, S. (2004): «Dispersed Knowledge and an Entrepreneurial Theory of the Firm», Journal of Business Venturing, 19: 659-679. 
Dobson, J. (2009): «Alasdair Macintyre's Aristotelian Business Ethics: A Critique», Journal of Business Ethics, 86: 43-50.

DRUCKER, P. (1998): El gran poder de las pequeñas ideas, Editorial Sudamericana, Buenos Aires.

EtZIONE, A. (1987): «Entrepreneurship, Adaptation and Legitimation», Journal of Economic Behavior and Organization, 8: 175189.

Freeman, E. (2000): «Business Ethics at the Millennium», Business Ethics Quarterly, 10(1): 169-180.

Friedman, M. (1970): «The Social Responsibility of Business is to Increase its Profits», New York Times Magazine, $13^{\text {th }}$ September.

Ghoshal, S. (2005): «Bad Management Theories are Destroying Good Management Practices», Academy of Management Learning \& Education 4(1): 75-91.

GHoshal, S. and BARLetT, C.A. (1997): The Individualized Corporation: A Fundamentally New Approach to Management, HarperCollins Publishers, New York.

Ghoshal, S., Bartlett, C., \& Moran, P. (1999): «A New Manifesto for Management», Sloan Management Review, 4(39): 9-20.

Harmeling, S., Sarasvathy, S. \& Freeman, R. (2009): «Related Debates in Ethics and Entrepreneurship. Values, Opportunities, and Contingency», Journal of Business Ethics, 84: 341365.

HANNAFEY, F. (2003): «Entrepreneurship and Ethics: a Literature Review», Journal of Business Ethics, 46(2): 99-110.

HAYEK, F. A. vON (1976 [1945]): «The Use of Knowledge in Society», in Individualism and Economic Order, Routledge and Kegan Paul, London.

- (1989): «The Pretence of Knowledge» (Nobel lecture), American Economic Review, December: 3-7.

HuerTA De Soto, J. (2010): Socialism, Economic Calculation and Entrepreneurship, Edward Elgar, Chetelham, UK.

KIRZNER, I. (1973): Competition and Entrepreneurship, University of Chicago Press, Chicago.

- (1979): Perception, Opportunity and Profit, University of Chicago Press, Chicago.

- (2000): The Driving Force of the Market, Routledge, London. 
Knight, F. (1921): Risk, Uncertainty and Profit, Augustus Kelly, NY. Koslowski, P. (1996): Ethics of Capitalism and Critique of Sociobiology, Springer Verlag, Berlin.

LeibesteIN, H. (1968): «Entrepreneurship and Development», American Economic Review, 58: 72-83.

MACHAN, T. (1999): «Entrepreneurship and Ethics», International Journal of Social Economics, 26(5): 596-606.

MaríAs, J. (1996): Persona, Alianza Editorial, Madrid.

Mises, L. vON (1996): Human Action: A Treatise on Economics, B.B. Greaves (ed.), $4^{\text {th }}$ edition revised, Foundation for Economic Education, New York.

Moore, G. (2002): «On the Implications of the Practice-Institution Distinction: MacIntyre and the Application of Modern Virtue Ethics to Business», Business Ethics Quarterly 12(1): 1932.

- (2005a): «Humanizing Business: A Modern Virtue Ethics Approach», Business Ethics Quarterly, 15(2): 237-255.

- (2005b): «Corporate Character: Modern virtue ethics and the Virtuous Corporation», Business Ethics Quarterly, 15(4): 659-685.

Moran, P., and Ghoshal, S. (1999): «Markets, Firms and the Process of Economic Development», Academy of Management Review, 24(3): 390-412.

Nelson, R. and Winter, S. (1982): An Evolutionary Theory of Economic Change, Harvard University Press, Cambridge, MA.

North, D. (1991): «Institutions», Journal of Economic Perspectives, 5(3): $97-112$.

Nussbaum, M. (2011): Creating Capabilities. The Human Development Approach, Belknap Press of Harvard University, Cambridge, MA.

Nussbaum, M. and Sen, A. (1993): The Quality of Life. Clarendon Press, Oxford.

PinCKAERS, S. (1985): Le sources de la morale chrétienne, University Press, Friburg.

Porter, M.E. (1996): «What is Strategy», Harvard Business Review, 74 (6): 61-78.

Richardson, H. (1997): Practical Reason about Final Ends, Cambridge University Press, Cambridge. 
- (2000): «Some Limitations of Nussbaum's Capabilities», Quinnipiac Law Review, 9: 309-332.

RobBins, L. (1969): An Essay on the Nature and Significance of Economic Science, $2^{\text {nd }}$ ed., Macmillan, London.

Shane, S. (2000): «Prior Knowledge and the Discovery of entrepreneurial Opportunities», Organizational Science, 11(4): 448469.

Shane, S. and Venkataraman, S. (2000): «The Promise of Entrepreneurship as a Field of Research", Academy of Management Review, 25(1): 217-226.

SCHUMPETER, J.A. (1934): Capitalism, Socialism and Democracy, Harper \& Row, New York.

- 1947: The Theory of Economic Development, Harvard University Press, Cambridge, MA.

Sen, A. (1999): Development as Freedom, Knopf, New York.

- (2002): Rationality and Freedom, Harvard Belknap Press, Harvard.

- (2009): The Idea of Justice, Harvard University Press, Harvard.

Simon, H.A. (1969): Sciences of the Artificial, MIT Press, Boston.

Solomon, R.C. (1992): Ethics and Excellence: Cooperation and Integrity in Business Oxford University Press, New York.

- (2004): «Aristotle, Ethics and Business Organizations», Organization Studies, 25 (6): 1021-1043.

Teece, D.J., Pisano, G. \& Shuen, A. (1997): «Dynamic Capabilities and Strategic Management», Strategic Management Journal 18: 509-534.

Venkataraman, S. (1997): «The Distinctive Domain of Entrepreneurship Research", Advances in Entrepreneurship, Firm Emergence and Growth, 3: 119-138. 